\title{
THE EFFECT OF SOME FUNGICIDES AND TOTAL SAPONIN ON SELECTED CHEMICAL COMPONENTS OF CERTAIN FUNGI
}

\author{
WAHEID, M. A., ${ }^{1}$ S. SH. RAMSES ${ }^{2}$ AND RANIA A. ABDOU ${ }^{2}$ \\ 1. Biochemistry Dept., Fac. of Agric., Ain Shams University \\ 2. Central Agricultural Pesticide Laboratory, ARC, Dokki, Giza
}

(Manuscript received 31 May 2009)

\begin{abstract}
The present study aimed to evaluate the effect of total saponin (TS) extracted from mulberry root bark and some fungicides using $\mathrm{EC}_{50}$ for each on the chemical components (total soluble sugars, free amino acids or total protein) and some enzymes (amylase, peroxidase, catalase, polyphenol oxidase (PPO), protease, polygalacturonase (PG), polymethyl esterase (PME) and cellulase of certain fungi i.e. Al. alternata, B. cinerea, F. oxysporum, R. solani and $S$. rolfsii. Electrophoresis studies were carried out on selected fungi grown in liquid media treated with total saponin at $\mathrm{EC}_{50}$ comparing with untreated media. Results concluded that, TS and carboxin fungicide decreased the biochemical components $F$. oxysporum, $R$. solani and $S$. rolfsii. Thiophanate-methyl and TS decreased total soluble sugars, free amino acids and total protein. The inhibition percentage of free amino acids and total protein in $B$. cinerea treated with thiophanate-methyl were 37.0 and 43.1, respectively, compared with the untreated controls. Amylase activity produced by $B$. cinerea treated with TS or thiophanatemethyl was decreased comparing with the untreated control. PPO activity was completely inhibited in $B$. cinerea when liquid media was treated with thiophanate-methyl. The reduction of catalase and protease activities was recorded in $B$. cinerea treated with TS or thiophanate-methyl and compared with the untreated control. Thiophanate-methyl induced a significant $(p<0.01)$ decrease in peroxidase activity produced by $B$. cinerea comparing with the untreatment, while the treatment with TS induced non significant decrease in peroxidase activity compared with the untreated control. Adding TS to liquid medium was more effective than thiophanate-methyl in reducing cellulase and PG activities produced by $B$. cinerea. Also, the treatment of liquid media with TS or thiophanate-methyl caused highly inhibition in PME activity, which reached 62.3 and $65.4 \%$, respectively. The reduction of free amino acids and total protein were observed in Al. alternata treated with TS or copper sulfate, which recorded $24.3,32.0 \%$ and 29.9, $46.2 \%$, respectively, of that produced in untreated media. Amylase activity produced by $A l$. alternata was completely inhibited other treatment with TS, while copper sulfate caused significant $(p<0.001)$ decrease in this enzyme compared to the untreated control. In contract, TS expressed non significant decrease in PPO activity, but, copper sulfate expressed a significant $(p<0.01)$ decrease in PPO activity produced by Al. alternata. TS and copper sulfate caused greatly decrease and significant $(p<0.01)$ protease activity comparing with the untreated control. The inhibition of protease activity for treated Al. alternata recorded 48.8 and $53.5 \%$, respectively. TS induced non significant decrease in preoxidase
\end{abstract}


activity, while, copper sulfate caused a low significant $(p<0.05)$ decrease in the enzyme activity produced by Al. alternata compared to the untreatment. In contract, TS was more effective than copper sulfate on the reduction of cellulase and PG activities. The electrophoresis studies showed that $S$. rolfsii was more sensitive to TS comparing with the other selected fungi.

\section{INTRODUCTION}

Saponins are widely distributed in nature, being present in more than 1730 plant species belonging to 104 families. Of these species 627 were found to contain triterpenoid saponins and 127 to contain steroidal saponins i.e. triterpenoidal saponins are most abundant in plant kingdom. The pentacyclic triterpenoid saponins are of rare occurrence in monocot-yledons. They are more frequent in dicotyledons, being abundant in Caryophyllaceae, Sapindaceae, Polygolaceae, Sapotaceae and of common occurrence in Phytolaccaceae, Zygophyllaceae, Oleaceae, Papaveraceae, Araliaceae, Linaceae, Rutaceae (Fenwick et al., 1991).

Until few years it was customary to classify the pentacyclic triterpenoids, according to Waffo-Teguo et al.,(2004), into three groups:-

1 - Oleanane, $\beta$-amyrin or oleanolic acid group.

2- Ursane, a-amyrin or ursolic acid group.

3- Lupane or lupeol-betulic acid group.

Several biological effects have been ascribed to saponins. Extensive research has been carried out into the membrane-permeability, immunostimulant, hypocholesterolaemic, antimicrobial, hepatoprotective, antiviral and anticarcenogenic properties of saponins and they have also been found to significantly affect growth, feed intake and reproduction in animals. These components can thus affect animals in a host of different ways both positive and negative.

\section{MATERIALS AND METHODS}

\section{Total Saponin}

Total saponin was prepared according to Ukpabi and Ukpabi, (2003). Root bark of mulberry was air-dried and ground to fine powder. The powder was soaked in petroleum ether $\left(40-60^{\circ} \mathrm{C}\right)$ for 24 hours to remove fats. The defatted powder was extracted with $50 \%$ aqueous methanol till exhaustion. The methanolic extract was reextracted whit $n$-butanol several times. The butanolic extract was evaporated till dryness. The residue was dissolved in small amount of alcohol. Then, the total saponin precipitated by addition of large amount of acetone (1:5 v/v). 


\section{Fungal strains}

Antifungal activity of total saponin and fungicides (shown in Table 1) was investigated against Alternaria alternata, Botrytis cinerea, Fusarium oxysporum, Rhizoctonia solani and Sclerotium rolfsii. All the tested fungal strains were maintained on Potato Dextrose Agar (PDA) medium (Oxiod CM 139) and were subcultured every two weeks.

Table 1. Trade, common and chemical names and active ingredient of tested fungicides.

\begin{tabular}{|c|c|c|c|}
\hline Traditional name & $\begin{array}{l}\text { Common name \& } \\
\text { Active ingredient }\end{array}$ & Chemical name & Formulation \\
\hline Del cup 6\% & $\begin{array}{c}\text { Copper sulfate } \\
(23.5 \%)\end{array}$ & Copper sulfate pentahydrate & Liquid \\
\hline Topsin-M 70\% & $\begin{array}{l}\text { Thiophanate-methyl } \\
(70 \%)\end{array}$ & $\begin{array}{l}\text { Dimethyle(1,2phenylene) bis } \\
\text { (iminocarbono-thioye) bis } \\
\text { cabonate }\end{array}$ & Waterable powder \\
\hline Vitavax-T & $\begin{array}{l}\text { Carboxin } \\
(75 \%)\end{array}$ & $\begin{array}{c}\text { 5,6-dihydro-2-methyl-N-phenyl- } \\
\text { 1,4-oxathiin-3-carboxyamide- } \\
\text { bis (dimethyl thio-carbamayl) } \\
\text { disulfide }\end{array}$ & Waterable powder \\
\hline
\end{tabular}

\section{Methods:}

\section{Laboratory experiments}

Effect of the tested fungicides and total saponin (TS) at $\mathrm{EC}_{50}$ on chemical components and enzymes produced by pathogenic fungi was studied.

In this experiment $2 \mathrm{ml}$ of total saponin or tested fungicides at $\mathrm{EC}_{50}$ Table (2) were added to $100 \mathrm{ml}$ of sterilized PD medium inoculated with 4 discs $(5 \mathrm{~mm})$ of any tested fungi and incubated at $\left(25 \pm 2^{\circ} \mathrm{C}\right)$. Five flasks were used for each particular treatment as replicates. When the mycelial growth covered the surface media in untreated flask (control), the mycelial matrix was excluded by filtration and dried at the room temperature over night. The dry mycelial mates were homogenated and chemical determinations were carried out.

*Table 2. Effective concentration inhibited $50 \%\left(\mathrm{EC}_{50}\right)$ of linear growth of each fungus

\begin{tabular}{|c|c|c|}
\hline \multirow{2}{*}{ Fungi } & \multicolumn{2}{|c|}{$\mathrm{EC}_{50}$ in $\mathrm{mm}$} \\
\cline { 2 - 3 } & Carbixn & Total saponin \\
\hline R. solani & 5.02 & 1056.9 \\
\hline S. rolfsii & 1.30 & 118.9 \\
\hline F. oxysporum & 10.01 & 2160.26 \\
\hline B. cinerea & Thiophenate-methyl & Total saponin \\
\hline & 0.89 & 938.1 \\
\hline Al. alternata & Copper-sulfate & Total saponin \\
\hline
\end{tabular}

*previous study by Sami and Rania 


\section{Chemical determinations of fungi}

\section{Determination of total soluble sugars.}

Total soluble sugars of fungi were determined according to Shaffer-Somogi micro method described in A.O.A.C. (1995).

\section{Quantitative assay of free amino acids as lysine}

Samples were prepared by extraction $0.5 \mathrm{~g}$ of each fungus by $25 \mathrm{ml}$ ethanol $80 \%$ (Jayaraman, 1985). A standard solution of lysine was prepared by dissolving $0.02 \mathrm{~g}$ lysine in $100 \mathrm{ml}$ of $80 \%$ ethanol. The color developed was measured using a spectrophotometer at wave length $570 \mathrm{~nm}$. The concentrations of free amino acids were calculated as lysine from the standard curve Fig.(1).

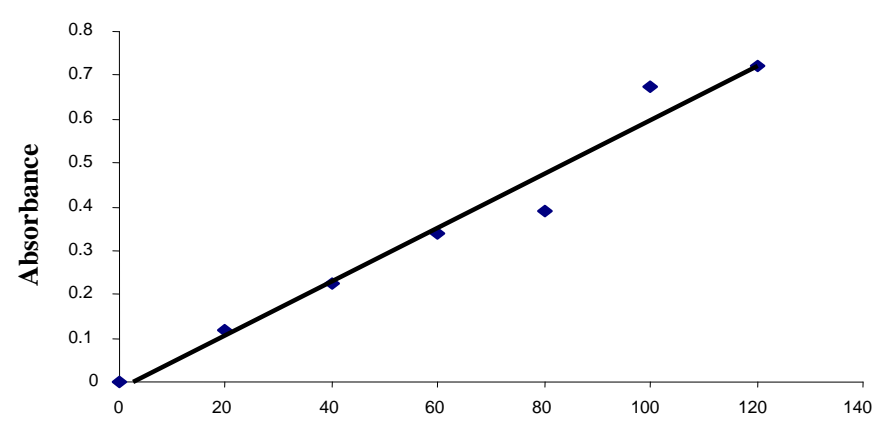

\section{Concentration $(\mu \mathrm{g} / \mathrm{ml})$}

Fig. 1. Standard curve of free amino acids determined colorimetrically as lysine at 570nm.

\section{Determination of total protein.}

A ratio of 1:2.5 (w/v) of each fungus to extraction buffer (0.125M Tris-borate, $\mathrm{pH}$ 8.9) was used. The soluble protein concentration was spectroscopically determined by referring to a calibration curve relating the concentration of authentically albumin bovine at 546nm (Fig.2) according to Lowery et al., (1951).

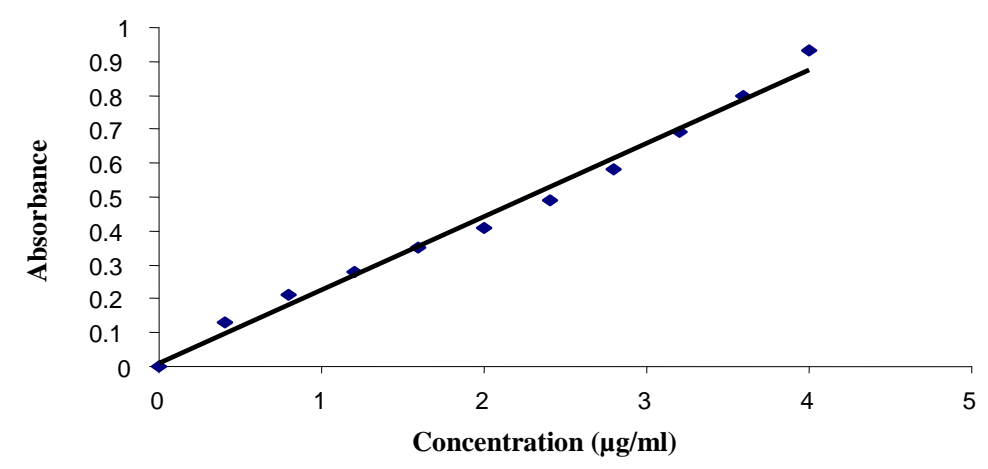

Fig. 2.) Standard curve of albumin bovine determined colorimetrically at $546 \mathrm{~nm}$. 


\section{Determination of total amylase activity.}

One gram of each fungus was homogenized in mortar with $4 \mathrm{ml} 0.01 \mathrm{M}$ Tris$\mathrm{HCl}$ buffer $\mathrm{pH} 8.0$ containing $0.02 \mathrm{M} \mathrm{NaCl}$ and $\mathrm{CaCl}_{2}$. The supernatant was used for total amylase activity according to the method described by Dewez et al., (2005). The total amylase activity is expressed as mg starch consumed/ 15min /1g fungus (Fig.3).

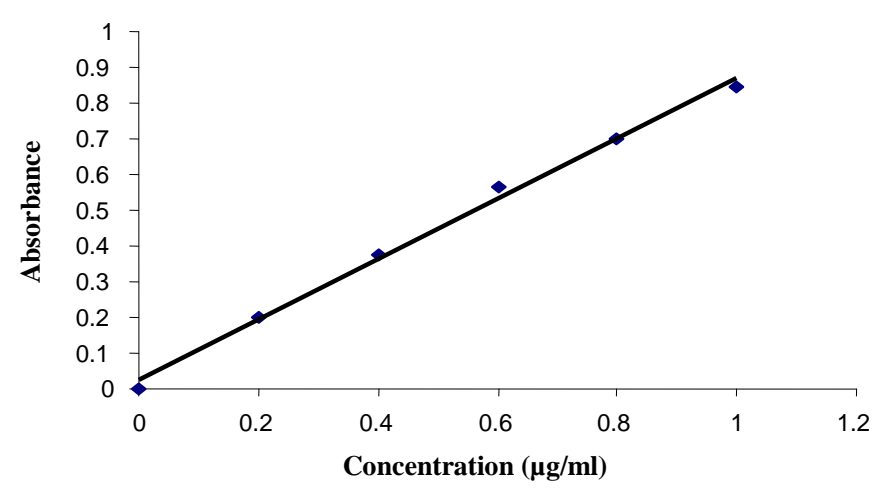

Fig. 3. Standard curve of starch determined colorimetrically at $660 \mathrm{~nm}$.

\section{Determination of peroxidase activity.}

One gram of each fungus was extracted two times with $0.1 \mathrm{M}$ potassium phosphate buffer $\mathrm{pH} 4.7$ containing $0.25 \mathrm{M}$ sucrose. The colorimetric assay of the total peroxidase in extract was conducted as described by Sreenivasulu et al., (1999). The peroxidase activity was expressed in a unit of the increase of absorption at $470 \mathrm{~nm}$ for $5 \mathrm{~min}$. per $\mathrm{g}$ fungus, designated as $\Delta$ O.D. $470 \mathrm{~nm} / 5 \mathrm{~min} / \mathrm{g}$ fungus.

\section{Determination of catalase activity.}

One gram of each fungus was homogenized two times with $0.01 \mathrm{M}$ phosphate buffer ( $\mathrm{pH}$ 7.0). Catalase activity was determined according to the method described by Dewez et al., (2005). The enzyme activity was determined as the change in absorbance at $240 \mathrm{~nm}$ per one gram fungus / $1 \mathrm{~min}$.

\section{Determination of polyphenol oxidase (PPO) activity.}

One gram of each fungus was extracted with citrate-phosphate buffer $(\mathrm{pH}$ 6.2) in ratio $1: 2(w / v)$. Enzyme assay was accomplished according to method described by Dewez et al., (2005). Results were expressed in units of PPO. One unit of PPO activity is defined as an increase of 0.1 unit absorbance per min at $420 \mathrm{~nm}$.

\section{Determination of protease activity.}

Protease activity was determined by method described by Dewez et al., (2005). The blue color developed was determined after $5 \mathrm{~min}$. at $625 \mathrm{~nm}$. 


\section{Determination of polygalacturonase (PG) activity.}

PG activity was assayed by estimating the loss in viscosity of $1.2 \%$ aqueous high methoxy pectin at $37^{\circ} \mathrm{C}$ by the method described by Echandi et al., (1957).

\section{Determination of poly methyl esterase (PME) activity.}

PME activity was determined by the titration method described by Matta and Dimond, (1963).

\section{Determination of cellulase activity.}

Cellulase activity was determined by measuring the loss in viscosity of carboxymethyl cellulase $(\mathrm{CMC})$ solution at $37^{\circ} \mathrm{C}$. The method described by Matta and Dimond, (1963).

\section{Electrophoretic studies.}

Electrophoresis of fungal filtrates (untreated and treated with total saponin) of soluble proteins was done. After incubation period of all pervious fungi which was grown on PD medium, the mycelial mats were separated using cheesecloth and ground in liquid nitrogen to a fine powder. The fungal powder $(0.5 \mathrm{~g})$ was mixed with $5 \mathrm{ml}$ of extraction buffer $(0.05 \mathrm{M}$ Tris- $\mathrm{HCl}$ pH $7.5,5 \%$ glycerol, $0.1 \% \quad \beta$ mercaptoethanol). The samples were centrifuged at $10000 \mathrm{rpm}$ for $45 \mathrm{~min}$. , at $4^{\circ} \mathrm{C}$ and the supernatant was collected. Fifty microlitter of protein fraction was added to the same volume of SDS sample buffer pH 6.8 (Laemmli, 1970) in eppendorf tube and boiled in water bath for $2 \mathrm{~min}$.

Electrophoresis was performed with a SDS-PAGE system (Laemmli, 1970) using $15.0 \%$ resolving gel $\mathrm{pH} 8.8,3.9 \%$ stacking gel $\mathrm{pH} 6.8$ and carried out at $150 \mathrm{~V}$ at $10^{\circ} \mathrm{C}$. After Electrophoresis, the gel was stained overnight in a general protein stain (Coomassie Brilliant Blue). It was distained in a solution of $50 \%$ methanol and $7 \%$ acetic acid in water and photographed.

Approximate molecular weights of protein bands $(\mathrm{kDa})$, were calculated according to standard proteins with known molecular weights and $\mathrm{Rm}$ values of the main protein bands were calculated according to the following formula:-

Distance of band from the origin

$$
\mathrm{Rm}=\overline{\text { Distance of bromophenol blue from the origin }}
$$




\section{RESULTS AND DISCUSSION}

\section{Effect of total saponin (TS) and carboxin on the biochemical components produced by $F$. oxysporum, $R$, solani and $S$. rolfsii.}

Tables (3), (4) and (5) showed the effect of the treatment liquid PD media with TS or carboxin fungicide at $\mathrm{EC}_{50}$ of each on total soluble sugars, free amino acids, total protein and enzyme activities produced by F. oxysporum, $R$. solani and $S$. rolfsii.

Results in Tables (3), (4) and (5) proved that, the PD liquid media treated with TS or carboxin induced significant decrease in total soluble sugars for $F$. oxysporum and $R$. solani comparing with the untreated media. Such effect was highly pronounced in case of treated $R$. solani with TS or carboxin, which reached 50 and $25 \%$, respectively of that recoded in the untreatment. No significant decreases in total soluble sugars for $S$. rolfsii were observed when the liquid media was treated with TS or carboxin at $\mathrm{EC}_{50}$, respectively.

Data also showed that, the reduction of free amino acids for the three fungi was observed due to the treatment of PD medium with TS or carboxin. Such effect was significant $(p>0.001)$ and pronounced in case of $S$. rolfsii was treated with carboxin comparing with untreated media reached $9.4 \pm 1.3$ and $19.4 \pm 1.6 \mathrm{mg} / 1 \mathrm{~g}$ fungus, respectively. The reduction percentages of free amino acids for F. oxysporum, $R$. solani and $S$. rolfsii were $(34.7,32.1),(31.7,22.0)$ and $(51.5,33.5)$ when liquid media was treated with carboxin or TS, respectively.

The same results trend was found with the inhibition of total protein for the three fungi. The inhibition of total protein was significant $(p<0.001)$ and pronounced when S. rolfsii was treated with TS or carboxin, reaching 41.1 and $62.5 \%$, respectively, compared to the untreated control. These results were similar to that reported by Lalitha and Venkataraman, (1991). They suggested that, the antifungal activity of saponins isolated from Madhuca butyracea seeds on Pythium sp., $R$. solani, S. rolfsii and F. oxysporum, may be due to reduction of biochemical components such as free amino acids and total protein which play role in growth and pathogenicity of their fungi.

Amylase activity in $S$. rolfsii and $F$. oxysporum was sharply reduced due to the treatment with TS $(0.8 \pm 0.11$ and $0.28 \pm 0.03)$ and carboxin $(0.8 \pm 0.01$ and $0.56 \pm 0.2)$ comparing with untreatment $(2.6 \pm 0.31$ and $2.04 \pm 0.1 \mathrm{mg}$ starch $/ \mathrm{g}$ fungus), respectively. Such effect was more noticeable in F. oxyspourum treated with TS and carboxin which equal 86.2 and $72.5 \%$ of that observed in untreated. The lowest effect was observed in case of $R$. solani treated with TS or carboxin which recorded 20.7 and $35.9 \%$, respectively, of that obtained in untreated. 
On the other hand, the reduction of polyphenol oxidase (PPO) activity was non significant in $S$. rolfsii and $R$. solani when the liquid media was treated with TS. PPO activity decreased significant in $S$. rolfsii and $R$. solani when it was treated with carboxin reaching 38.9 and $36.6 \%$ comparing with untreated control, while, PPO activity was not detected in F. oxysporum.

Data in Tables (3), (4) and (5) indicated that, the treatment with TS or carboxin exerted non significant decrease in catalase activity for F. oxysporum. While, it caused significant decrease in the enzyme activity for $S$. rolfsii and $R$. solani, respectively. The reduction of catalase activity was more pronounced in $R$. solani treated with TS or carboxin reaching 51.0 and $35.0 \%$, respectively, of that obtained in untreated PD media.

Protease activity for F. oxysporum and $R$. solani was greatly inhibited result of TS or carboxin treatment at $\mathrm{EC}_{50}$. Such effect was significant $(\mathrm{p}<0.001)$ carboxin treatment. The reduction of the enzyme activity in F. oxysporum and $R$. solani treated with carboxin was pronounced being 74.7 and 59.4\%, respectively, compared with the untreated control, but it was not detected in case of $S$. rolfsii.

The treated PD liquid media with $\mathrm{TS}$ at $\mathrm{EC}_{50}$ for the three fungi induced non significant decrease in peroxidase activity compared with the untreated control. While, the treatment with carboxin expressed significant $(p<0.001)$ decrease in the enzyme activity produced by these fungi. Such effect was greatly noticeable in $S$. rolfsii which recorded completely inhibition in peroxidase activity due to the treatment with carboxin. While, the reduction of the enzyme activity for $R$. solani and $F$. oxysporum treated with carboxin was 38.2 and $29.0 \%$, respectively, compared with the untreated medium.

Contrarly, of that, the treatment with TS on the three fungi was more affective than carboxin on cellulase and polygalacturonase (PG) activities. The reduction of cellulase and PG activities were highly significant $(\mathrm{p}<0.001)$ in case of $S$.

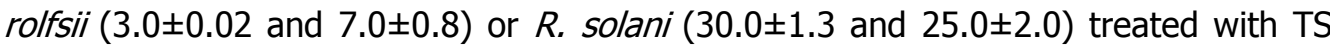
comparing with the untreated control which equal (13.0 2.4 and $10.0 \pm 1.6)$ or

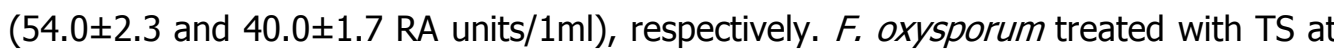
$E_{50}$, showed significant decrease $(p<0.05)$ in cellulase and PG activities compared with the untreated control reaching $(24.0 \pm 1.8,29.2 \pm 2.6)$ and $(30.0 \pm 2.1,35.0 \pm 3.2$ RA units $/ 1 \mathrm{ml}$ ), respectively. Cellulase activity in $S$. rolfsii treated with TS was greatly, being $76.9 \%$ of the untreated control.

On the other hand, the treatment with carboxin to R. solani and F. oxysporum caused non significant decrease in cellulase and PG activities comparing with the untreated control. S. rolfsii treated with carboxin showed significant reduction of 
cellulase and PG activities comparing with the untreated control. The inhibition of cellulase and PG activities in $S$. rolfsii treated with carboxin were pronounced reaching 60.8 and $20.0 \%$, respectively, of that detected in the untreated control, (Tables 3, 4 and 5).

Table 3. Effect of total saponin $(A)$ and carboxin $(B)$ at $\left(E C_{50}\right)$ on total soluble sugars, free amino acids, total protein and enzymes activities produced by $R$. solani

\begin{tabular}{|c|c|c|c|}
\hline Parameters & Untreated & (A)-treated & (B)-treated \\
\hline Total soluble sugars ( $\mathrm{g} / \mathrm{g}$ fungus) & $0.4 \pm 0.001$ & $0.02 \pm 0.001 * * *$ & $0.03 \pm 0.001 *$ \\
\hline$\%$ & 0.0 & 50.0 & 25.0 \\
\hline Free amino acids (mg/1g fungus) & $4.1 \pm 0.1$ & $3.2 \pm 0.2^{* *}$ & $2.8 \pm 0.1 * *$ \\
\hline$\%$ & 0.0 & 22.0 & 31.7 \\
\hline Total protein (mg/1g fungus) & $11.0 \pm 1.3$ & $8.5 \pm 1.5^{*}$ & $7.0 \pm 0.8^{* *}$ \\
\hline$\%$ & 0.0 & 22.7 & 63.4 \\
\hline Amylase activity (mg starch $/ 1 \mathrm{~g}$ ) & $14.5 \pm 1.5$ & $11.5 \pm 1.1^{*}$ & $9.3 \pm 1.3^{*}$ \\
\hline$\%$ & 0.0 & 20.7 & 35.9 \\
\hline PPO activity (O.D. /5min) & $0.737 \pm 0.1$ & $0.697 \pm 0.1$ & $0.467 \pm 0.09 *$ \\
\hline$\%$ & 0.0 & 5.4 & 36.6 \\
\hline Catalase activity (O.D. /1min) & $0.617 \pm 0.08$ & $0.401 \pm 0.01 * *$ & $0.532 \pm 0.02 *$ \\
\hline$\%$ & 0.0 & 51.0 & 35.0 \\
\hline Protease activity (O.D. $/ 5 \mathrm{~min}$ ) & $0.704 \pm 0.2$ & $0.365 \pm 0.1^{* *}$ & $0.286 \pm 0.01 * *$ \\
\hline$\%$ & 0.0 & 48.2 & 59.4 \\
\hline Peroxidase activity (O.D. $/ 5 \mathrm{~min}$ ) & $0.432 \pm 0.1$ & $0.401 \pm 0.02$ & $0.267 \pm 0.01 * *$ \\
\hline$\%$ & 0.0 & 7.2 & 38.2 \\
\hline Cellulase activity (RA units $/ 1 \mathrm{ml}$ ) & $54.0 \pm 2.3$ & $30.0 \pm 1.3^{* * *}$ & $40.0 \pm 2.5^{*}$ \\
\hline$\%$ & 0.0 & 44.4 & 25.9 \\
\hline PG activity (RA units / $1 \mathrm{ml}$ ) & $40.0 \pm 1.7$ & $25.0 \pm 2.0 * * *$ & $34.0 \pm 3.5$ \\
\hline$\%$ & 0.0 & 37.5 & 15.0 \\
\hline PME activity (meq acid /1ml/ hr) & $0.36 \pm 0.04$ & $0.24 \pm 0.01 * * *$ & $0.20 \pm 0.01 * * *$ \\
\hline$\%$ & 0.0 & 33.3 & 44.4 \\
\hline
\end{tabular}

Results are expressed as mean \pm SE for 4 replicates in each group.

$\%$ : the percentage of inhibition.

*significant $p<0.05$

$* * p<0.01$

$* * * \mathrm{p}<0.001$

The treatment with $\mathrm{TS}$ or carboxin at $\mathrm{EC}_{50}$ in the liquid medium induced significant decrease in pectin methyl esterase (PME) activity in the three fungi except F. oxysporum treated with TS. In general, carboxin fungicide was more effective than TS in reducing the PME activity in the three fungi. Such effect was highly significant ( $\mathrm{p}<0.001$ ) and pronounced in $R$. solani, followed by F. oxysporum and S. rolfsii, which 
the inhibition percentage equal to 44.4 .26 .1 and 23.6 , respectively, of that recorded in untreated

R. solani, S. rolfsii and F. oxysporum produces PG, cellulase and PME adaptively. A high correlation exists between the ability of $R$. solani to produce large quantities of PG in vitro and their pathogenicity. PG was primarily responsible for tissue maceration. Whereas, cellulase seemed to play a secondary role in the process. There was no consistent relation between PME activity and tissue maceration (Bateman, 1993).

Table 4. Effect of total saponin $(A)$ and carboxin $(B)$ at $\left(E C_{50}\right)$ on total soluble sugars, free amino acids, total protein and enzymes activities produced by $S$. rolfsii

\begin{tabular}{|c|c|c|c|}
\hline Parameters & Untreated & (A)-treated & (B)-treated \\
\hline Total soluble sugars ( $\mathrm{g} / \mathrm{g}$ fungus) & $0.05 \pm 0.001$ & $0.048 \pm 0.01$ & $0.05 \pm 0.01$ \\
\hline$\%$ & 0.0 & 4.0 & 0.0 \\
\hline Free amino acids (mg/ $1 \mathrm{~g}$ fungus) & $19.4 \pm 1.6$ & $12.9 \pm 2.0 *$ & $9.4 \pm 1.3 * * *$ \\
\hline$\%$ & 0.0 & 33.5 & 51.5 \\
\hline Total protein (mg/1g fungus) & $5.6 \pm 0.8$ & $3.3 \pm 0.5^{* * *}$ & $2.1 \pm 0.1 * * *$ \\
\hline$\%$ & 0.0 & 41.1 & 62.5 \\
\hline Amylase activity (mg starch $/ 1 \mathrm{~g}$ ) & $2.6 \pm 0.31$ & $0.8 \pm 0.11^{* *}$ & $0.8 \pm 0.1 * *$ \\
\hline$\%$ & 0.0 & 66.4 & 66.4 \\
\hline PPO activity (O.D. $/ 5 \mathrm{~min}$ ) & $0.656 \pm 0.1$ & $0.532 \pm 0.1$ & $0.401 \pm 0.01 * *$ \\
\hline$\%$ & 0.0 & 18.9 & 38.9 \\
\hline Catalase activity (O.D. /1min) & $0.617 \pm 0.01$ & $0.510 \pm 0.01 *$ & $0.500 \pm 0.02 *$ \\
\hline$\%$ & 0.0 & 17.3 & 19.0 \\
\hline Protease activity (O.D. $/ 5 \mathrm{~min}$ ) & n.d. & n.d. & n.d. \\
\hline Peroxidase activity (O.D. /5min) & $0.723 \pm 0.2$ & $0.548 \pm 0.01 * *$ & n.d. \\
\hline$\%$ & 0.0 & 24.2 & 100 \\
\hline Cellulase activity (RA units $/ 1 \mathrm{ml}$ ) & $13.0 \pm 2.4$ & $3.0 \pm 0.02 * * *$ & $5.1 \pm 0.1 * *$ \\
\hline$\%$ & 0.0 & 76.9 & 60.8 \\
\hline PG activity (RA units / $1 \mathrm{ml}$ ) & $10.0 \pm 1.6$ & $7.0 \pm 0.8^{* * *}$ & $8.0 \pm 1.1^{*}$ \\
\hline$\%$ & 0.0 & 30.0 & 20.0 \\
\hline PME activity (meq acid $/ 1 \mathrm{ml} / \mathrm{hr}$ ) & $0.55 \pm 0.02$ & $0.42 \pm 0.01 * *$ & $0.47 \pm 0.01 *$ \\
\hline$\%$ & 0.0 & 14.5 & 23.6 \\
\hline
\end{tabular}

Results are expressed as mean \pm SE for 4 replicates in each group.

$\%$ : the percentage of inhibition.

n.d: not detected

*significant $\mathrm{p}<0.05$

$* * \mathrm{p}<0.01$

$* * * \mathrm{p}<0.001$ 
Table 5. Effect of total saponin $(A)$ and carboxin $(B)$ at $\left(E_{50}\right)$ on total soluble sugars, free amino acids, total protein and enzymes activities produced by $F$. oxysporum

\begin{tabular}{|c|c|c|c|}
\hline PARAMETERS & UNTREATED & (A)-TREATED & (B)-TREATED \\
\hline Total soluble sugars ( $\mathrm{g} / \mathrm{g}$ fungus) & $0.018 \pm 0.001$ & $0.014 \pm 0.001^{*}$ & $0.015 \pm 0.001 *$ \\
\hline$\%$ & 0.0 & 22.2 & 16.7 \\
\hline Free amino acids (mg/ $1 \mathrm{~g}$ fungus) & $47.6 \pm 3.5$ & $32.3 \pm 0.15^{* *}$ & $31.1 \pm 1.3^{* *}$ \\
\hline$\%$ & 0.0 & 32.1 & 34.7 \\
\hline Total protein (mg/1g fungus) & $4.8 \pm 1.1$ & $3.3 \pm 0.5^{*}$ & $3.0 \pm 0.8^{* *}$ \\
\hline$\%$ & 0.0 & 33.3 & 37.5 \\
\hline Amylase activity (mg starch $/ 1 \mathrm{~g}$ ) & $2.04 \pm 0.1$ & $0.28 \pm 0.03 * *$ & $0.56 \pm 0.2 *$ \\
\hline$\%$ & 0.0 & 86.2 & 72.5 \\
\hline PPO activity (O.D. $/ 5 \mathrm{~min}$ ) & n.d. & n.d. & n.d. \\
\hline Catalase activity (O.D. /1min) & $0.732 \pm 0.01$ & $0.701 \pm 0.01$ & $0.691 \pm 0.02 *$ \\
\hline$\%$ & 0.0 & 4.2 & 5.6 \\
\hline Protease activity (O.D. $/ 5 \mathrm{~min})$ & $0.407 \pm 0.03$ & $0.192 \pm 0.01 * *$ & $0.103 \pm 0.01 * *$ \\
\hline$\%$ & 0.0 & 52.8 & 74.7 \\
\hline Peroxidase activity (O.D. $/ 5 \mathrm{~min})$ & $0.334 \pm 0.002$ & $0.313 \pm 0.001$ & $0.237 \pm 0.01 * *$ \\
\hline$\%$ & 0.0 & 6.3 & 29.0 \\
\hline Cellulase activity (RA units / $1 \mathrm{ml}$ ) & $30.0 \pm 2.1$ & $24.0 \pm 1.8^{*}$ & $28.0 \pm 1.9$ \\
\hline$\%$ & 0.0 & 20.0 & 6.7 \\
\hline PG activity (RA units /1ml) & $35.0 \pm 3.2$ & $29.2 \pm 2.6 *$ & $33.0 \pm 2.6$ \\
\hline$\%$ & 0.0 & 17.1 & 5.7 \\
\hline PME activity (meq acid /1ml/ hr) & $0.23 \pm 0.01$ & $0.21 \pm 0.001$ & $0.17 \pm 0.001^{* *}$ \\
\hline$\%$ & 0.0 & 8.7 & 26.1 \\
\hline
\end{tabular}

Results are expressed as mean \pm SE for 4 replicates in each group.

$\%$ : the percentage of inhibition. n.d: not detected

$*$ significant $\mathrm{p}<0.05 \quad * * \mathrm{p}<0.01$

From these results we can conclude that TS or carboxin fungicide may inhibit the growth of the three fungi and pathogenicity by decreasing their biochemical components. This conclusion was in agreement with that reported by Muhsin et al., (2000). They recommended using saponin extracted from garlic extract to inhibit enzyme production and activity in order to suppress fungal pathogenicity 


\section{The effect of TS and thiophanate-methyl fungicide on the biochemical components produced by $B$. cinerea.}

Table (6) shows the effect of the treatment of liquid media with TS or thiophanate-methyl fungicide $\left(\mathrm{EC}_{50}\right)$ each on total soluble sugars, free amino acids, total protein and enzymes activities produced by $B$. cinerea.

The liquid medium PD treated with TS or thiophanate-methyl at $\mathrm{EC}_{50}$ caused significant decrease in total soluble sugars of $B$. cinerea comparing with untreatment. Such decrease was a significant $(p<0.01)$ and pronounced in case of the treatment with TS comparing with untreatment which reached $0.04 \pm 0.001$ and $0.061 \pm 0.001 \mathrm{~g} / 1 \mathrm{~g}$ fungus, respectively. The inhibition of total soluble sugars in fungus treated with TS was $34.4 \%$, of the untreated control.

Adding TS or thiophanate-methyl $\left(E_{50}\right)$ to liquid medium resulted a significant decrease in free amino acids and total protein for $B$. cinerea. This result was significant $(p<0.001)$ and pronounced when the liquid media was treated with thiophanate-methyl comparing with untreatment. The inhibition percentage of free amino acids and total protein in $B$. cinerea treated with thiophanate-methyl were 37.0 and 43.1, respectively, comparing with untreatment, (Table 6).

Amylase activity in $B$. cinerea treated with TS or thiophanate-methyl showed significant $(p<0.05)$ decrease comparing with the untreated control, reaching $0.69 \pm 0.01,0.70 \pm 0.01$ and $0.81 \pm 0.07 \mathrm{mg}$ starch $/ 1 \mathrm{~g}$ fungus, respectively. On the other hand, completely inhibition in PPO activity for $B$. cinerea occurred when liquid media was treated with thiophanate-methyl $\left(E_{50}\right)$, while, the treatment with TS expressed non significant decrease in PPO activity compared to the untreated control.

Results (Table 6) illustrated the reduction of catalase and protease activities in $B$. cinerea treated with TS or thiophanate-methyl comparing with the untreated control. Such effect was highly significant $(p<0.001)$ and pronounced in the thiophanate-methyl treatment. The inhibition of catalase and protease activities reached 23.0 and $50.8 \%$, of the untreated control respectively. Similarly, thiophanatemethyl $\left(E_{50}\right)$ induced significant $(\mathrm{p}<0.01)$ decrease in peroxidase activity produced by $B$. cinerea comparing with the untreated control which equal to $0.401 \pm 0.02$ and $0.516 \pm 0.030 . D / 5 \mathrm{~min}$, respectively. The treatment with TS showed non significant decrease in peroxidase activity compared to untreated control.

These results were in agreement with that recorded by (Adrian et al., 1997). They indicated that, Resveratrol, a stilbene produced by grapes (Vitis spp.), inhibited the spread of $B$. cinerea infection. Laccase produced by this fungus is assumed to detoxify resveratrol. In recent studies, it was shown that a specific laccase of $B$. 
cinerea dose not detoxify resveratrol but converts it into compounds more toxic for the fungus (Schouten et al., 2002).

Adding TS $\left(E_{50}\right)$ to liquid medium was more effective than thiophanatemethyl on the reduction of cellulase and PG activities produced by $B$. cinerea. The inhibition of cellulase and PG activities was 40.0 and 37.5\%, respectively, of that obtained in the untreated control. Also, the treatment with TS or thiophanate-methy at $\mathrm{EC}_{50}$ to liquid media caused highly inhibition in PME activity, reaching 62.3 and $65.4 \%$, respectively, of that recorded in the untreated control. These results were similar to that reported by Muhsin et al., (2000).

Table 6. Effect of total saponin (A) and thiophanate-methyl (B) $\left(E_{50}\right)$ on total soluble sugars, free amino acids, total protein and enzymes activities produced by B. cinerea

\begin{tabular}{|c|c|c|c|}
\hline Parameters & Untreated & (A)-treated & (B)-treated \\
\hline Total soluble sugars ( $\mathrm{g} / \mathrm{g}$ fungus) & $0.061 \pm 0.001$ & $0.040 \pm 0.001^{*}$ & $0.55 \pm 0.001$ \\
\hline$\%$ & 0.0 & 34.4 & 9.8 \\
\hline Free amino acids (mg/ $1 \mathrm{~g}$ fungus) & $16.2 \pm 0.5$ & $12.6 \pm 1.5^{* *}$ & $10.2 \pm 1.0^{* *}$ \\
\hline$\%$ & 0.0 & 22.2 & 37.0 \\
\hline Total protein (mg/1g fungus) & $10.2 \pm 1.5$ & $8.6 \pm 0.5$ & $5.8 \pm 0.4 * * *$ \\
\hline$\%$ & 0.0 & 15.7 & 43.1 \\
\hline Amylase activity (mg starch /1g) & $0.81 \pm 0.07$ & $0.69 \pm 0.01 *$ & $0.70 \pm 0.01$ \\
\hline$\%$ & 0.0 & 14.8 & 13.6 \\
\hline PPO activity (O.D. $/ 5 \mathrm{~min}$ ) & $0.529 \pm 0.12$ & $0.415 \pm 0.1$ & n.d. \\
\hline$\%$ & 0.0 & 21.6 & $100 ? ? ? ?$ \\
\hline Catalase activity (O.D. /1min) & $0.731 \pm 0.02$ & $0.570 \pm 0.01 *$ & $0.563 \pm 0.01^{* * *}$ \\
\hline$\%$ & 0.0 & 32.0 & 50.8 \\
\hline Protease activity (O.D. $/ 5 \mathrm{~min}$ ) & $0.309 \pm 0.2$ & $0.207 \pm 0.1 *$ & $0.152 \pm 0.01 * * *$ \\
\hline$\%$ & 0.0 & 48.2 & 59.4 \\
\hline Peroxidase activity (O.D. /5min) & $0.516 \pm 0.03$ & $0.500 \pm 0.01$ & $0.401 \pm 0.02 * * *$ \\
\hline$\%$ & 0.0 & 3.1 & 22.3 \\
\hline Cellulase activity (RA units /1ml) & $40.0 \pm 4.2$ & $24.0 \pm 3.5^{* *}$ & $35.0 \pm 2.5$ \\
\hline$\%$ & 0.0 & 40.0 & 12.5 \\
\hline PG activity (RA units /1ml) & $32.0 \pm 2.7$ & $20.0 \pm 5.6^{* *}$ & $32.0 \pm 2.6$ \\
\hline$\%$ & 0.0 & 37.5 & 0.0 \\
\hline PME activity (meq acid /1ml/ hr) & $0.28 \pm 0.01$ & $0.10 \pm 0.01 * * *$ & $0.097 \pm 0.01 * * *$ \\
\hline$\%$ & 0.0 & 62.3 & 65.4 \\
\hline
\end{tabular}

Results are expressed as mean \pm SE for 4 replicates in each group.

$\%$ : the percentage of inhibition.

n.d: not detected

*significant $p<0.05$

$* * p<0.01$

$* * * \mathrm{p}<0.001$ 


\section{Effect of total saponin (TS) and copper sulfate fungicide on the biochemical components produced by Al. alternata.}

Table (7) illustrated that, the effect of the treatment on PD liquid media with TS and copper sulfate fungicide at $\mathrm{EC}_{50}$ of each on total soluble sugars, free amino acids, total protein and enzymes activities produced by Al. alternata.

TS and copper sulfate at $\mathrm{EC}_{50}$ induced significant decrease in total soluble sugars in Al. alternata. Such effect was highly significant $(p<0.001)$ and noticeable in case of the treatment with TS, which reached $47.4 \%$ of the untreated control. As well as, the reduction of free amino acids and total protein were observed in Al. alternata treated with TS or copper sulfate, which recorded $24.3,32.0 \%$ and $29.9,46.2 \%$, respectively, of that produced in untreated media.

Data in Table (7) proved that, amylase activity produced by Al. alternata was completely inhibited when it was treated with TS. Copper sulfate caused highly significant $(p<0.001)$ decrease in this enzyme compared with the untreated control, reaching $0.36 \pm 0.01$ and $0.96 \pm 0.03 \mathrm{mg}$ starch/ $1 \mathrm{~g}$ fungus, respectively, (i.e. $62.5 \%$ of the untreated media). Contrarily, TS expressed non significant decrease in PPO activity, but, copper sulfate showed significant $(p<0.01)$ decrease in PPO activity in $A /$. alternata.

A significant reduction of catalase activity in Al. alternata treated with TS or copper sulfated was found when TS was added to the media comparing with the untreated control being $0.513 \pm 0.01$ and $0.801 \pm 0.11$ O.D/1min., respectively. Additionally, TS and copper sulfate at $\mathrm{EC}_{50}$ caused significant reduction $(\mathrm{p}<0.01)$ in protease activity comparing with the untreated control. The inhibition of protease activity in Al. alternata treatment recorded 48.8 and $53.5 \%$, respectively, of that detected in the untreatment, (Table 7).

TS induced non significant decrease in preoxidase activity, while, copper sulfate caused significant $(p<0.05)$ decrease in this enzyme produced by Al. alternata compared to the untreated control, being $0.491 \pm 0.03$ and $0.683 \pm 0.02$ O.D/ 5 min., respectively. Contrarily, the treatment of liquid media with $\mathrm{TS}$ at $\mathrm{EC}_{50}$ was more effective than copper sulfate on the reduction of cellulase and PG activities. The inhibition rates of cellulase and PG activities were 56.8 and $31.4 \%$ in Al. alternata treated with TS, comparing with 18.9 and $14.3 \%$, respectively, of that recorded in untreatment, in copper sulfate treatment. PME activity was not detected in $\mathrm{Al}$. alternata. These results were similar to that reported by Muhsin et al., (2000). 
Table 7. Effect of total saponin (A) and copper sulfate $(B)$ at $\left(E C_{50}\right)$ on total soluble sugars, free amino acids, total protein and enzymes activities produced by Al. alternata.

\begin{tabular}{|c|c|c|c|}
\hline Parameters & Untreated & (A)-treated & (B)-treated \\
\hline Total soluble sugars ( $\mathrm{g} / \mathrm{g}$ fungus) & $0.019 \pm 0.001$ & $0.010 \pm 0.01 * * *$ & $0.015 \pm 0.001 *$ \\
\hline$\%$ & 0.0 & 47.4 & 21.1 \\
\hline Free amino acids (mg/ $1 \mathrm{~g}$ fungus) & $21.4 \pm 1.8$ & $16.2 \pm 2.0 *$ & $15.0 \pm 1.5^{* *}$ \\
\hline$\%$ & 0.0 & 24.3 & 29.9 \\
\hline Total protein ( $\mathrm{mg} / \mathrm{lg}$ fungus) & $5.2 \pm 0.7$ & $4.0 \pm 0.2^{*}$ & $2.8 \pm 0.1 * * *$ \\
\hline$\%$ & 0.0 & 32.0 & 46.2 \\
\hline Amylase activity (mg starch $/ 1 \mathrm{~g}$ ) & $0.96 \pm 0.03$ & N.D. & $0.36 \pm 0.01 * * *$ \\
\hline$\%$ & 0.0 & $100 ? ? ?$ & 62.5 \\
\hline PPO activity (O.D. $/ 5 \mathrm{~min}$ ) & $0.489 \pm 0.08$ & $0.411 \pm 0.1$ & $0.304 \pm 0.05^{* *}$ \\
\hline$\%$ & 0.0 & 16.0 & 38.0 \\
\hline Catalase activity (O.D. /1min) & $0.801 \pm 0.11$ & $0.513 \pm 0.01 * *$ & $0.721 \pm 0.1$ \\
\hline$\%$ & 0.0 & 36.0 & 10.0 \\
\hline Protease activity (O.D. $/ 5 \mathrm{~min}$ ) & $0.619 \pm 0.17$ & $0.317 \pm 0.08^{* *}$ & $0.288 \pm 0.05^{* *}$ \\
\hline$\%$ & 0.0 & 48.8 & 53.5 \\
\hline Peroxidase activity (O.D. $/ 5 \mathrm{~min}$ ) & $0.683 \pm 0.02$ & $0.600 \pm 0.05$ & $0.491 \pm 0.03 *$ \\
\hline$\%$ & 0.0 & 12.2 & 28.1 \\
\hline Cellulase activity (RA units /1ml) & $37.0 \pm 4.2$ & $16.0 \pm 5.8^{* *}$ & $30.0 \pm 3.6$ \\
\hline$\%$ & 0.0 & 56.8 & 18.9 \\
\hline PG activity (RA units /1ml) & $35.0 \pm 3.8$ & $24.0 \pm 2.5^{* *}$ & $30.0 \pm 5.3$ \\
\hline$\%$ & 0.0 & 31.4 & 14.3 \\
\hline PME activity (meq acid /1ml/ hr) & n.d. & n.d. & n.d. \\
\hline
\end{tabular}

Results are expressed as mean \pm SE for 4 replicates in each group.

$\%$ : the percentage of inhibition.

n.d: not detected

*significant $p<0.05$

$* * p<0.01$

$* * * p<0.001$

\section{Electrophoresis study}

Electrophoresis studies were carried out on selected fungi grown in liquid media treated with $\mathrm{TS}$ at $\mathrm{EC}_{50}$ comparing with the untreated media, (Table 8).

The electrophoretic protein pattern of $B$. cinerea treated with TS and untreatment was presented in lane 2 and 1, respectively. Results showed that, the intensity of the four bands with MW about 90.0, 66.0, 58.0 and 20.0kDa decreased in the treated $B$. cinerea comparing with the untreated control. The absence the band with MW 116.0kDa and the new synthesized band with MW 64.0kDa were observed 
resulting from the treatment of the liquid media with TS comparing with the untreated control.

The electrophoretic protein pattern of $S$. rolfsii treated with TS and the untreatment is presented in lane 4 and 3, respectively. The results indicated that the intensity of the three bands with MW about 90.0, 66.0 and 45.0kDa decreased in the treated $S$. rolfsii comparing with untreated control. The absent bands with MW 116.0 and 97.0kDa with the new synthesized bands with MW 36.0 and 20.0kDa were detected due to the treatment of the liquid media with TS comparing with the untreated control.

In case of $R$. solani, the electrophoretic protein pattern of fungus treated with TS and the untreatment are presented in lane 6 and 5, respectively. Data in Table (8) showed that the intensity of the four bands with MW about 97.0, 36.0, 10.0 and $6.5 \mathrm{kDa}$ decreased in the treated $R$. solani comparing with the untreated control. While, absence bands with MW 90.0, 84.0, 66.0, 64.0, 49.0 and 14.2kDa were observed resulting from the treatment of the liquid media with TS comparing with the untreated control.

The electrophoretic protein pattern of $F$. oxysporum treated with TS and the untreated is presented in lane 8 and 7, respectively. The results demonstrated that the intensity band with MW about 116.0kDa decreased in the treatment comparing with the untreated control. The increasing in intensity of bands with MW of about 64.0 and 58.0kDa with the new synthesized band with MW 20.0kDa observed as a result of the treatment of the liquid media with TS comparing with the untreated control (Table 8).

Finally, the electrophretic protein pattern of Al. alternata treated with TS and untreated was presented in lane 10 and 9, respectively. These results indicated that there was no change in protein pattern of $A /$. alternata when liquid media was treated with $\mathrm{TS}$ at $\mathrm{EC}_{50}$ comparing with untreated medium.

From these results it is concluded that $S$. rolfsii was more sensitive to TS comparing with the other selected fungi. 
Table 8. SDS-PAGE patterns of soluble protein fraction extracted from selected fungi treated with TS $(T)$ and untreated media (C).

\begin{tabular}{|c|c|c|c|c|c|c|c|c|c|c|c|}
\hline \multirow{2}{*}{$\begin{array}{l}\text { M.W. } \\
(\mathrm{kDa})\end{array}$} & \multirow[b]{2}{*}{ M } & \multicolumn{2}{|c|}{ B. cinerea } & \multicolumn{2}{|c|}{ S. rolfsii } & \multicolumn{2}{|c|}{ R. solani } & \multicolumn{2}{|c|}{ F. oxysporum } & \multicolumn{2}{|c|}{ Al. alternata } \\
\hline & & C & $\mathrm{T}$ & C & $\mathrm{T}$ & C & $\mathrm{T}$ & C & $T$ & $\mathrm{C}$ & $\mathrm{T}$ \\
\hline 205.0 & --- & & & & & & & & & --- & --- \\
\hline 116.0 & --- & --- & & --- & & & & +++ & --- & --- & --- \\
\hline 97.0 & --- & & & --- & & +++ & --- & --- & --- & --- & --- \\
\hline 90.0 & & +++ & --- & +++ & --- & --- & & & --- & & \\
\hline 84.0 & --- & --- & --- & & & --- & & --- & --- & & \\
\hline 66.0 & --- & +++ & --- & +++ & --- & --- & & & & & \\
\hline 64.0 & & & --- & & & --- & & --- & +++ & --- & --- \\
\hline 58.0 & & +++ & --- & & & & & --- & +++ & & \\
\hline 55.0 & --- & --- & --- & & & --- & --- & & & --- & --- \\
\hline 49.0 & & & & & & --- & & --- & --- & & \\
\hline 45.0 & --- & & & +++ & --- & & & & & & \\
\hline 36.0 & --- & & & & --- & +++ & --- & --- & --- & & \\
\hline 30.0 & --- & & & & & & & & & & \\
\hline 24.0 & --- & & & & & & & & & & \\
\hline 20.0 & -- & +++ & --- & & --- & --- & -- & & --- & --- & --- \\
\hline 14.2 & --- & & & & & --- & & & & & \\
\hline 10.0 & & & & & & +++ & --- & --- & --- & & \\
\hline 6.5 & --- & & & & & +++ & --- & --- & --- & & \\
\hline
\end{tabular}

+++ : increase in intensity when compared $\mathrm{C}$ with $\mathrm{T}$ both of fungus.

The study showed that the treatment of the fungi with saponin extract caused decrease in the amount of the secreted enzymes (amaylase, PPO, catalase, cellulase, peroxidase and PG) of the fungi compared with the untreated control of the extract which may be related to inhibition of mycilium growth of these fungi.

\section{REFERENCES}

1. A.O.A.C. 1995. Official methods of analysis of the association of official analytical chemists. $15^{\text {th }}$ ED. Published by the association of official analytical chemists. INC. suite 400,200 Wilson Baulevard. Arligton Virgina 22201 USA., pp.69-90.

2. Adrian, M., P. Jeandet, J. Veneau, L. Weston and R. Bessis. 1997. Biological activity of resveratrol, a stilbenic compound from grapevines, against Botrytis cinerea the causal agent for gray mold. J. Chem. Ecol.23:1689-1702. 
3. Bateman, D.F. 1993. The "Macerating Enzyme" of Rhizoctonia solani. Phytopathol.14:1179-1185.

4. Dewez, D., L. Geoffroy, G. Vernet and R. Popovic. 2005. Determination of photosynthetic and enzymatic biomarkers sensitivity used to evaluate toxic effects of copper and fludioxonil in alga Scenedesmus obliquus. Aquatic Toxicol. 74:150159.

5. Echandi, E.S., D. Van-Gundy and J.C. Walker. 1957. Pectolytic enzymes secreted by soft rot bacteria. Phytopathol. 47:549-552.

6. Fenwick, G.R., K.R. Price, C. Tsukamoto and K. Okubo. 1991. Saponins in Toxic Substances in Crop Plants, (Dmello F.J.P., Duffus C.M. and J.H. Duffus, editors). Cambridge: The Royal Society of Chemistry. PP.361,362.

7. Jayaraman, J. 1985. Laboratory Manual in Biochemistry. PP.132-135. Wiley Eastern Limited. New Delhi, N.Y.

8. Laemmli, U.K. 1970. Cleavage of structural proteins during the assembly of the head of bacteriophage T4. Nature Lond. 227,680-685.

9. Lalitha, T. and L.V. Venkataraman. 1991. Antifungal activity and mode of action of saponins from Madhuca butyracea. Indian J. Experimental Biolo, 29(6):558-562.

10. Lowery, O.H., N.J. Rosebrough, A.L. Farr and R.J. Randall. 1951. Protein measurement with the folin phenol reagent. J. Biol. Chem. 193:265-275.

11. Matta, A. and A.F. Dimond. 1963. Symptoms of Fusarium sp. in relation to quantity of fungus and enzyme activity in tomato stems. Phytopathol. 53:574-578.

12. Muhsin, T.M., S.R. Al-Zubaidy and E.T. Ali. 2000. Effect of garlic bulb extract on the growth and enzymatic activities of rhizosphere and rhizoplane fungi. Mycopathologia 152:143-146.

13. Schouten, A., L. Wagemarers, F.T. Stefanata, R.M.V.D. Kaaij and J.A.L.V. Kan. 2002. Resveratrol acts a natural pro fungicide and induces self-intoxication by a specific laccase. Mol. Microbio. 43:883-894.

14. Sreenivasulu, N., S. Ramanjulu, K. Ramachandra-Kini, H.S. Prakash and C. Sudhakar. 1999. Total peroxidase activity and peroxidase isoforms as modified by salt stress in two cultivars of fox-tail millet differential salt tolerance. Plant Sci. 141:1-9.

15. Ukpabi, U.H. and U.J. Ukpabi. 2003. Potential of seeds of Napoleona imperialis (P.beaur) as a source of hemolytic saponin and feed ingredients. Lifestock Research for Rural Development 15(12):103-112.

16. Waffo-Teguo, P., L. Voutquenne, O. Thoison, V. Dumontet, V.H. Nguyen and C. Lavaud. 2004. Acetylated glucuronide triterpene bidesmosidic saponins from Symplocos glomerata. Phytochem. 65: 741-750. 
تأثير بعض المبيدات الفطرية والصابونين الكلي علي المحتوي الكيميائي لبعض الفطريات

وحيذ محمد عفيفي' ، سامي شفيق رمسيس ، ، رانيا عبده عبده حسين

$$
\begin{aligned}
& \text { ا ـ قسم الكيبياء الحبوية ، كلية الزراعة ، جامعة عبن شمس }
\end{aligned}
$$

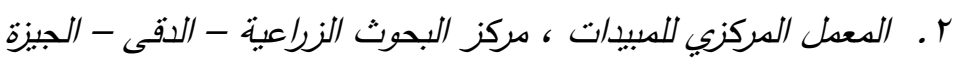

تهدف هذه الدراسة الي قياس تأثثر استخدام المبيدات الفطرية ومركب الصابونين الكلي المستخلص

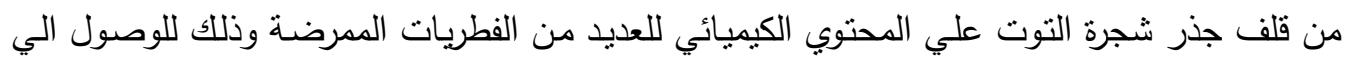
طريقة ومكان فعل هذه المركبات داخل الفطر حيث تم في هذه الدراسـة استخدام المبيدات الفطريـة كربوكسين و كبريتات النحاس وثيوفينات الميثيل وكذلك مركب الصابونين الكلي بالتركيز المثبط لنصف Al. alternata, B. cinarea, F. oxysporum, R. solani and S. النمو الميسليومي (EC50) للفطريات rolfsii

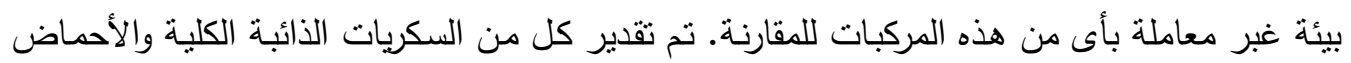

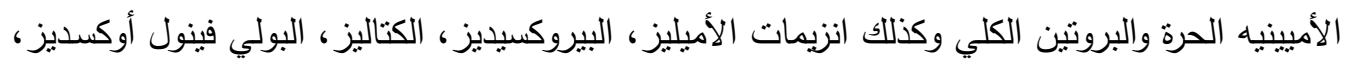

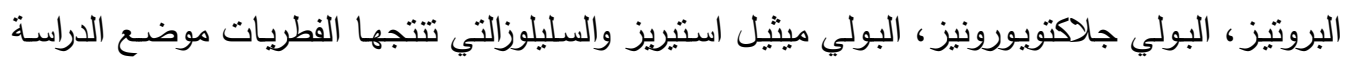

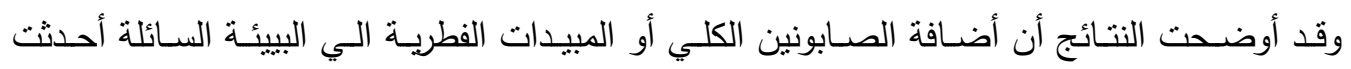

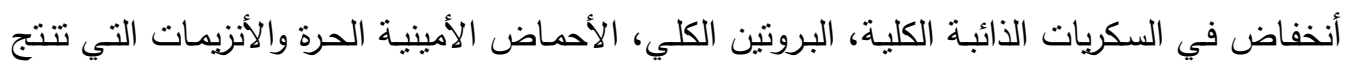
بواسطة هذه الفطريات والتي لها دور في نموها وتسممها هذه الفطريات وقد لوحظ أن المبيدات الفطرية الفية الفينة

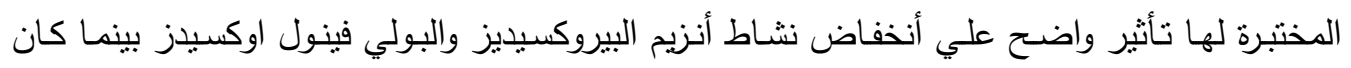
تأثثير الصابونين الكلي واضح علي أنخفاض نشاط أنزيمات تحلل السليلوز ، بولي جلاكتويورونيز ، بولي ولئي

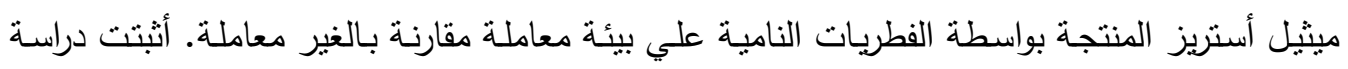

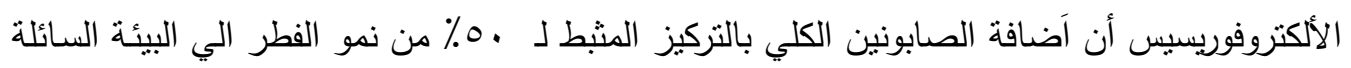

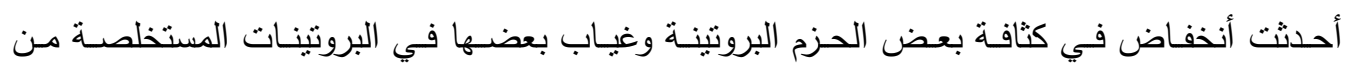

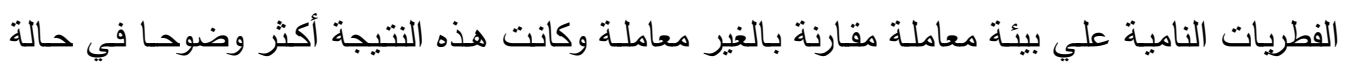
ف فري B. cinarea و . r. rolfsii 